\title{
カーボン/ポリイミド複合材料における 引張機械的性質の統計的評価
}

\author{
下河 利行*，濱口 泰正 †，角田 義秋士，三本木茂夫\$，森野 美樹"，山本 昌孝 \\ (1994 年 3 月 8 日受付)
}

\author{
Statistical Evaluation of Tensile Mechanical Properties \\ of Carbon/Polyimide Composites
}

\author{
T. Shimokawa, ${ }^{*}$ Y. Hamaguchi, ${ }^{\dagger}$ Y. KakUta,, S. Sanbongi,$\S$ \\ Y. MORINO"l and M. YAMAMOTO"
}

(Received March 8, 1994)

\begin{abstract}
The objective of this study is to statistically evaluate tensile mechanical properties of two kinds of carbon/polyimide composites, i.e., Celion 6K/PMR-15 and T800H/PMR-15 with a quasi-isotropic stacking sequence. Tensile tests were conducted under room temperature using about thirty smooth specimens each. Mechanical properties measured are ultimate strength, failure strain, elastic modulus, and Poisson's ratio. Statistical analyses use four kinds of distribution models such as normal, log-normal, type-I extreme-value, and two-parameter Weibull distributions. These analyses derive the estimates of central tendencies and scatter parameters, and B allowables. Moreover, the modified Kolmogorov-Smirnov goodness-of-fit test for the four kinds of distribution models is applied for the data of each mechanical property. Correlation between mutual mechanical properties is examined, and a multiple regression analysis applied to predict the ultimate strength.
\end{abstract}

*-1 航空宇宙技術研究所機体部（181 三鷹市大沢 613-1)

Airframe Division, National Aerospace Laboratory, 6-13-1 Ohsawa, Mitaka, Tokyo 181, Japan

* 遮労研究室長 Head of Fatigue Section

†,t 主任研究官 Senior Research Engineers

$\S$ 航空宇宙技術研究所構造力学部（182 調布市深大 寺東町 7-44-1)

Structural Mechanics Division, National Aerospace Laboratory, 7-44-1 Jindaiji-Higashi, Chofu, Tokyo 182, Japan

総括室長 Head of Engineering Section

II 宇宙開発事業団システム技術開発部（305つくば 市千現 2-1-1)

Systems Engineering Department, National Space Development Agency of Japan, 2-1-1 Sengen, Tsukuba, Ibaraki 305, Japan 主任開発部員 Senior Engineer

I宇宙開発事業団宇宙往還システム室（182 調布市 深大寺東町 7-44-1)

Space Recovery Systems Office, National Space Development Agency of Japan, 7-44-1 JindaijiHigashi, Chofu, Tokyo 182, Japan

主任開発部員 Senior Engineer

\section{1. 緒言}

カーボン/ポリイミドは，耐熱性のあるプラスチック 系複合材料である. 使用温度範囲としては， 1 分間程度 であれば $430 〜 480^{\circ} \mathrm{C}$ から，10 万時間を目標とすれば $180 \sim 230^{\circ} \mathrm{C}$ 程度までと考えられている.このような性 質から、ミサイル, 宇宙往還機, シェェッ・ェンジン部 品, 先進戦闘機, および超音速輸送機に対する有力な主 棈造用材料として期待されている.この材料による実構 造開発の試みは一時活発に行われ，その成果が多数報告 されている1,2). しかしながら，その後の進歩について はほとんど公表されていない状況にある. また，この材 料に関する機械的性質の研究発表は幾つ吕3-6) 散見され るが，実用的データ7,8) は少ない。

我が国に揖いて，この材料を主構造用材料として実用 化するために本格的な材料評価に取組んたのは，航空宇 宙技術研究所（航技研）と宇宙開発事業団が最初であ る ${ }^{9-12)}$. 最近では, IHI でも評価試験が進められてい る13). しかしながら，この材料を主構造用として実用化 するためには，さらに多くの材料試験を蓄積すると同時 に,これらの結果を検討しながら，材料そのものや製造 
工程の改善を図り，より完成度の高い材料に成長させる 必要がある。

航技研と宇宙開発事業団はカーボン/ポリイミド複合 材料を無人宇宙往還機 HOPE (H-II Orbiting Plan E) の主構造に応用するため，共同で一連の評価試験を実施 している. 本研究はその一部として実施したものであ り，纎維が異なる 2 種類のカーボン/ポリイミド複合材 料について, 多数の試験片を用いて引張試験を実施し, 機械的性質に関する統計的データを導いたるのである. また，得られたデータに対して解析を行い，機械的性質 の統計的特性を明らかにした。ここではこれらの結果に ついて報告する。 なお，カーボン/ポリイミド複合材料 について，ここで報告するよらなデータと解析結果を公 表した例は他に見当たらない。

\section{2. 試験片と試験方法}

使用した 2 種類のプリプレグ・システムは, ファイバ ーライト社の Celion 6K/PMR-15 と T800H/PMR-15 である. プリプレグの公称厚さはそれぞれ 0.137 および $0.134 \mathrm{~mm}$ である. 試験片の形状を Fig. 1 に示す. 積 層㯨成としては潔準的な準等方積層 $(45 / 0 /-45 / 90) 4 \mathrm{~S}$ 32 プライを採用した. 供試材料の成形と試験片への加工 は 2 社が担当し, Celion 6K/PMR-15 の場合が A 社., $\mathrm{T} 800 \mathrm{H} / \mathrm{PMR}-15$ の場合がB社である.

引張試験の際には，試験片中央部表裏の荷重方向とこ れと沾角方向に計 4 枚の歪ゲージを貼りつけ，荷重一奀 関係を計测した，なお，補助的に試験片のクロスヘッド 間の変位も計測した、試験環境は室温である，使用した 試験片の数は, Celion 6K/PMR-15 の場合が 31 個, T800H/PMR-15 の場合が 30 個である. 試験は Celion

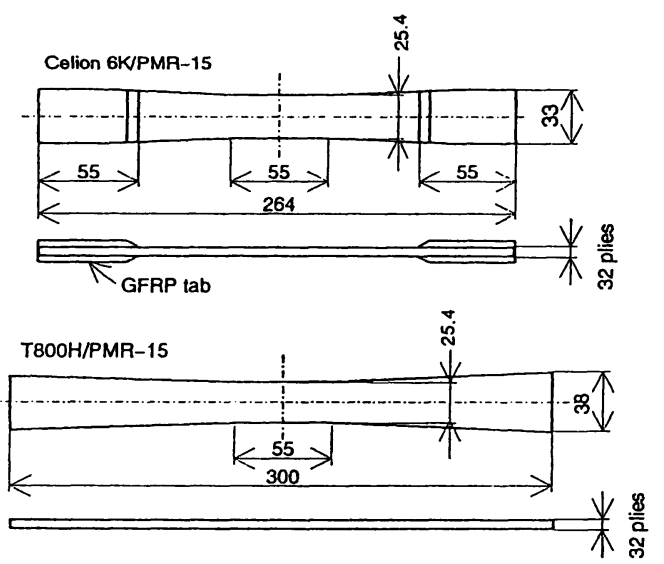

Fig. 1 Specimen configurations (in $\mathrm{mm}$ ).
6K/PMR-15 の場合が航技研で, T800H/PMR-15 の場 合はB社で行った，測定項目は，試験片に対する板厚と

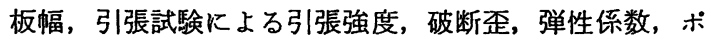
アソン比である.

\section{3. 統計的解析方法}

本研究では，機械的性質の分布モデルとして著者の一 人が提唱しているように ${ }^{14)} 4$ 種類の分㛂形を検討の対象 とする.ここでは，これらの分布関数を示すとともに， その母数推定值とばらつきの指標, および設計で使用さ れる MIL-HDBK-5F15) に定義されているB許容値（信 頼度 $=1-P=90 \%$, 信頼水準 $=1-\gamma=95 \%$ ）の計算方法 を示す.ささに, 本研究で使用した各分布形への適合度 検定法, 各機械的性質相互の相関係数の計算法, および 重回㷌分析法を簡単に説明する.

\subsection{4 種類の分布関数とばらつきの指標}

機柀的珄質の分布にあてはめる統計モデルとしては正 規系の正規分布，対数正規分布，およびワイブル系の極 値分布 (最小値の 2 重指数分布)，2 母数ワイブル分布 の計 4 種類とする. なお， 2 母数ワイブル分布は対数 2 重指数分布でもある. したがって，四規系分布とワイブ ル系分布の対応を考える際には，正規分布と極値分布， 対数正規分布と 2 母数ワイブル分布がそれぞれ対応す る. 2 母数分布を分布モデルとして採用するなら，この 4 種類を考えれば実用的には十分である。

\section{1 .1 正規分 布}

䜣規分布の場合，任意の機械的性質を $x$ とすれは， $x$ の確率密度関数は

$$
f(x)=\frac{1}{\sqrt{2 \pi} \sigma} \exp \left\{-\frac{(x-\mu)^{2}}{2 \sigma^{2}}\right\}
$$

で与えられる. ここで， $\mu$ と $\sigma$ はそれぞれ $x$ の平均と標 準偏差であり，正規分布の母数である. また，ばらつき の指標としては標準偏差を使用することもあるが，本研 究では変動係数 $\eta$

$$
\eta=\sigma / \mu
$$

を使うものとする。

\section{1 .2 対数正規分布}

対数正規分布の場合は， $X=\log x$ の確率密度関数が 正規分布となる. 式(1)において，xの代わりに $X, \mu$ の代わりに $\mu_{\mathrm{L}}, \sigma$ の代わりに $\sigma_{\mathrm{L}}$ と护けばよい，したが って，母数は $\mu_{\mathrm{L}}$ と $\sigma_{\mathrm{L}}$ であり，またばらつきの指慓に は $\sigma_{\mathrm{L}}$ を使用する.

\subsection{3 極値分布（最小値の 2 重指数分布）}

本研究で使ら極値分布の定義は，最小値の 2 重指数分 
布を指するのとする. 分布関数は

$$
F(x)=1-\exp \left[-\exp \left(\frac{x-x_{\mathrm{E}}}{b}\right)\right]
$$

で与えられる.ここで，x と 尺度母数である。、いま中央值を $x_{\mathrm{ME}}$ とすれば，

$$
x_{\mathrm{ME}}=x_{\mathrm{E}}+b \cdot \ln (\ln 2)
$$

で与えられる. 正規分布における変動係数の上らに極值 分布でも变動係数相当量を $\eta_{\mathrm{E}}$ とし，

$$
\eta_{\mathrm{E}}=b / x_{\mathrm{ME}}
$$

と定義する。これをばらつきの指標として使用する。

\section{1 .42 母数ワイブル分布}

2 母数ワイブル分布に打ける $x$ の分布関数は

$$
F(x)=1-\exp \left[-\left(x / x_{\mathrm{C}}\right)^{\alpha}\right]
$$

で与えられる. ここで， $x_{\mathrm{C}}$ は尺度母数， $\alpha$ は形状母数 である. いま, $X=\ln x, X E=\ln x_{\mathrm{C}}, b=1 / \alpha$ とおけば， 式(6)は式(3)に一致する. このために，2母数ワイブ ル分布は対数 2 重指数分布とも呼ばれる.ばらつきの指 標は $\alpha て ゙$ 裴される。

\subsection{4 種類の分布モデルに対する母数推定法}

本研究で便用する母数推定法を述へる. いま, 試験個 数を $n$ とする. 变数 $x$ の観测值を小さいほらから並べ, 順序番号 $i$ をつけて表するのとする. なお，数式表示を

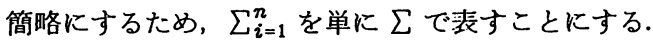

\section{2 .1 正規系分布の場合}

正規分布に対しては，標本平均 $\bar{x}$ と標本標準偏差 $s$

$$
s=\sqrt{\left\{\sum\left(x_{i}-\bar{x}\right)^{2}\right\} /(n-1)}
$$

を母数の推定値として使う。一方，ばらつきの指慓であ る変動係数の推定值は，これらを式 (2)に代入して得ら れる.

対数正規分布の場合には， $x$ の代わりに $X=\log x$ を 用いて計算すればよい，中央值は，式(7)により対数平 均 $\bar{X}$ を求めて真数に值した值で裴す。ばらつきの指僄 には式(8)に $X_{i}$ と $\bar{X}$ を代入し, 僄本対数標蕉偏差 $s_{\mathrm{L}}$ を計算して用いる.

\section{2 .2 ワイブル系分布の場合}

極值分布と 2 母数ワイブル分布に対しては，それぞれ の確率紙上にメジアンランクを使用して観测值をプロッ トし，最小 2 乗法により母数を推定するものとする。い まメジフンランクが与える累積確率を $P_{i}$ とする。ここ で, $E_{i}$ とその平均 $\bar{E}$ を

$$
\begin{gathered}
E_{i}=\ln \left[\ln \left\{1 /\left(1-P_{i}\right)\right\}\right] \\
\bar{E}=\sum E_{i} / n .
\end{gathered}
$$

とおく.
極值分布の場合，尺度母数と位置母数それぞれの推定 量 $\widehat{b} お よ ひ ゙ \widehat{x}_{\mathrm{E}}$ は

$$
\begin{gathered}
\widehat{b}=\left(\sum x_{i} \cdot E_{i}-n \bar{x} \bar{E}\right) /\left(\sum E_{i}{ }^{2}-n \bar{E}^{2}\right) \\
\widehat{x}_{\mathrm{E}}=\bar{x}-\widehat{b} \overline{\bar{E}}
\end{gathered}
$$

で与えられる. したがって，中央値の推定值 $\widehat{x}_{\mathrm{ME}}$ は得 られた $\hat{b} ， \hat{x}_{\mathrm{E}}$ を式(4)に代入して得られる.これによ り变動係数相当量の推定値 $\hat{\eta}_{\mathrm{E}}$ む式 (5)により計算でき る.

2 母数ワイブル分布の場合は， $x$ の代わりに $X=\ln x$ とおいて，式(11) と（12）により $\hat{b} と \hat{X}_{\mathrm{E}}$ を求める.する と， 2 母数ワイブル分布の形状母数 $\alpha$, 尺度母数 $x_{\mathrm{C}}$, 拧 よび中央値 $x_{\mathrm{MW}}$ の推定值はそれぞれ， $\hat{\alpha}=1 / \hat{b}, \hat{x_{C}}=$ $\exp \left(\widehat{X}_{E}\right), \widehat{x}_{M W}=\hat{x}_{C}(\ln 2)^{1 / \hat{\alpha}}$ により計算できる.

\subsection{B 許容値の計算法}

\subsection{1 正規系分布の場合}

正規分布に対するB許容値 $x_{\mathrm{B}}$ は，式(7)，（8）を 使い

$$
x_{\mathrm{B}}=\bar{x}-k \cdot s
$$

により導かれる. ここで， $k$ は片側許容限係数であり測 定個数 $n$, 信頼度 $1-P$, 信頼水準 $1-r$ の関数であり, 統計数值表 ${ }^{16)}$ に揭载されている.

刘数讯規分布の場合は, $\log x$ についてのB許容值を 導き，真数に㨁した值を採用すればよい，

\subsection{2 ワイブル系分布の場合}

極値分布と 2 母数ワイブル分布に対する B 許容値の計 算には，本研究では母数の推定方法がメジアンランクと 最小 2 乗法を使用しているから，著者の一人が与えた数 表(7)を使用することができる. 片側許容限界を計算する ためには $V_{\mathrm{P}}(1-r)$ の数裴を利用する.

極値分布の場合は，式(11) と（12）による計算値を使用 ᄂて,

$$
x_{\mathrm{B}}=\hat{x}_{\mathrm{E}}-\hat{b} \cdot V_{\mathrm{P}}(1-r)
$$

により計算される.

2 母数ワイブル分布の場合は，X=ln $x$ とおいて， $\widehat{X}_{\mathbf{E}}$ と $\widehat{b}$ を導き,

$$
x_{\mathrm{WB}}=\exp \left\{\widehat{X}_{\mathrm{E}}-\hat{b} \cdot V_{\mathrm{P}}(1-\gamma)\right\}
$$

により計算する.

\section{4 修正コルモゴロフ・スミルノフ適合度検定}

統計的分布モデルへの適合性を検討するために，修正: コルモゴロフ・スミルノフ適合度検定を使う。母数が末 知の場合, 修正コルモジロフ・スミルノフ適合度検定の 統計量 $D_{n}$ は, 両側検定の表現式 


$$
\begin{gathered}
D_{n}=\max _{1 \leqq i \leq n}\left(\delta_{i}\right) \\
\delta_{i}=\max \left[\Phi\left(x_{i} ; \hat{\theta}_{1}, \hat{\theta}_{2}\right)-(i-1) / n,\right. \\
\left.i / n-\Phi\left(x_{i} ; \hat{\theta_{1}}, \widehat{\theta 2}\right)\right]
\end{gathered}
$$

で表される ${ }^{18)}$.ここで, $\hat{\theta}_{1}, \hat{\theta}_{2}$ は母数の推定値, $\Phi(\cdot)$ は 分布関数を表す.なお，4種類の分布モデルそれぞれに 対する適合度検定を行うためには，著者の一人が与えた $D_{n}$ の限界値 ${ }^{19)}$ を使用すればよい。

\section{5 相関 係 数}

各機械的性質間の相関関係を調べるために相関係数を 計算する. 大きさの順を $i て ゙ ， 2$ 種の観測値を $x_{i}, y_{i}$ で 表すと, 2 変数 $x, y$ の相関係数 $r_{x y}$ は

$$
r_{x y}=\frac{\sum\left(x_{i}-\bar{x}\right) \cdot\left(y_{i}-\bar{y}\right)}{\sqrt{\sum\left(x_{i}-\bar{x}\right)^{2} \sum\left(y_{i}-\bar{y}\right)^{2}}}
$$

で与えられる.ここで， $\bar{x}, \bar{y}$ はそれぞれ平均值である。

\section{6 重回帰分析}

陉研究では, あまり例のない試みとして三つの機栈的
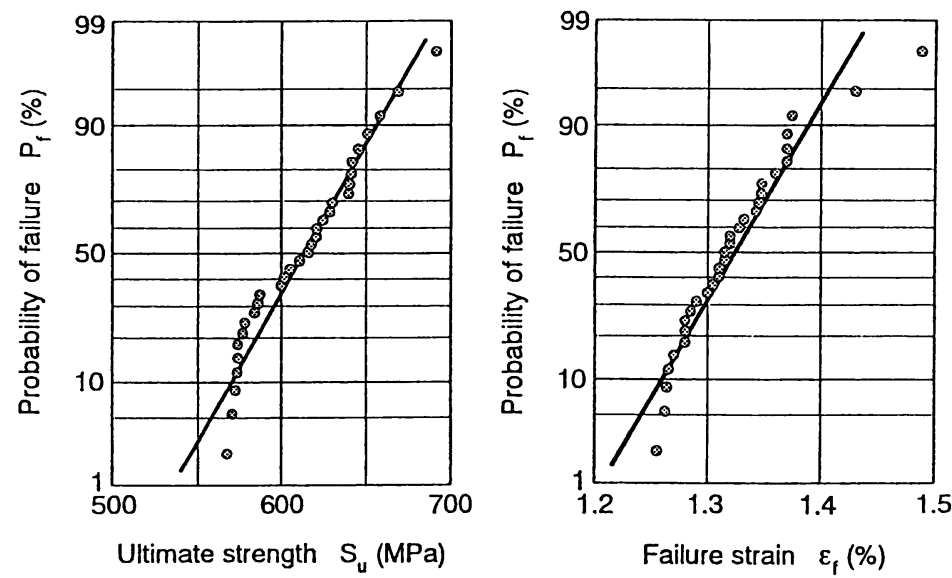

性質間の関係に対し重回帰分析を適用してみる。いま， 一つの性質が二つの変数に依存するとして, 目的変数を

$z, 2$ 種の説明变数を $x, y$ で表す. すると重回㷌式は

$$
z=a+b_{1} x+b_{2} y
$$

で与えられる.ここで， $a$ は切片， $b_{1}, b_{2}$ は偏回㷌係数 と呼ばれる. いま， $x$ の標準偏差 $s_{x}$ を

$$
s_{x}=\sqrt{\sum\left(x_{i}-\bar{x}\right)^{2 / n}}
$$

とおけば, $b_{1}, b_{2}, a$ はそれぞれ

$$
\begin{gathered}
b_{1}=\frac{s_{z}}{s_{x}} \cdot \frac{r_{z x}-r_{x y} y r_{y z}}{1-r_{x} y^{2}} \\
b_{2}=\frac{s_{z}}{s_{y}} \cdot \frac{r_{z} y-r_{x y} r_{x z}}{1-r_{x} y^{2}} \\
a=\bar{z}-b_{1} \bar{x}-b_{2} \bar{y}
\end{gathered}
$$

で与えられる，なお，sおよび $r$ なりたサフィックス はそれぞれの変数に対応する数式を意味する.

\section{ここで，重相関係数 $R_{m}$ は}

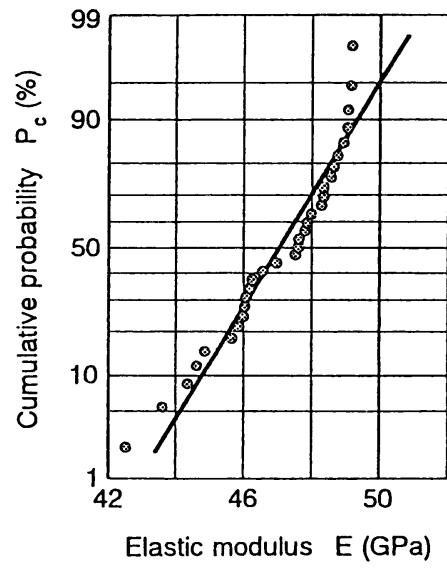

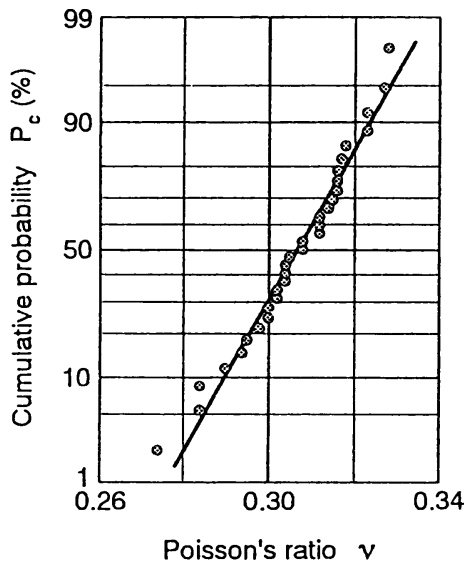

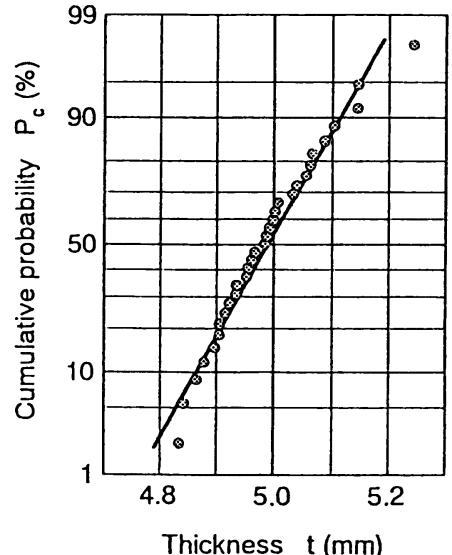

Fig. 2 Distributions of the mechanical properties and specimen thickness of a Celion $6 \mathrm{~K} / \mathrm{PMR}-15$ laminate plotted on normal probability paper. 


$$
R_{m}=\sqrt{\frac{r_{z x^{2}}+r_{z} y^{2}-2 r_{z x} r_{z} y r_{x y}}{1-r_{x} y^{2}}}
$$

により計算できる.

\section{4. 試験結果と解析}

\section{1 試 験 結 果}

試験結果は，実用的見地からプリプレグの公称厚さに より計算した板厚を用いて整理した。したがって，各機 械的性質は公称值である. 引張試験により得られた結果 を、メジアンランクを使用して正規確率紙にプロット し, Celion 6K/PMR-15 の場合を Fig. 2, T800H/ PMR-15 の場合を Fig. 3 に示す. 引張強度, 破断歪, 弾性係数, およびポアソン比は, どちらの材料について も測定した.

これらの図から，正規分布に対する適合度は Celion 6K/PMR-15 の弾性係数の場合のみよくないが，その他
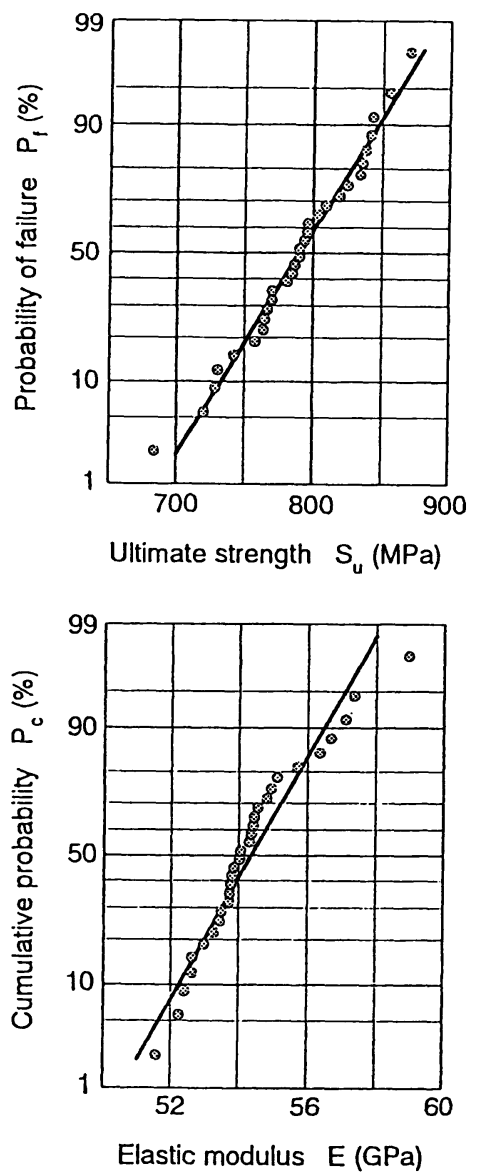

の場合は正規分布として解析しても妥当な結果と考えら れる. 4 種類の分布形に対する定量的適合度については 後記するが，この点については定量的にも裏付けられ る.

\section{2 代表値, ばらつき,およびB許容值}

Table $1 k$ Celion 6K/PMR-15 の機械的性質と板厚 の代表值、ばらつき,および B許容値の計算結果を,

Table 2 に T800H/PMR-15 の場合の結果を示す. 引張 強度, 破断歪, 弾性係数のいずれかに対しても, 代表值 すなわち平均, 中央値, 位置母数，あるいは尺度母数に よって比べると，新世代のカーボン繊維を使用した T800H/PMR-15 は Celion 6K/PMR-15 に比べて非常 に優れた結果を示している．また，ばらつきを変動係数 により比べると，破断歪の場合は T800H/PMR-15 の場 合が Celion 6K/PMR-15 の場合の約 1.8 倍と少々大き いが，これ以外は同等とみなせる．ポアソン比の代表值
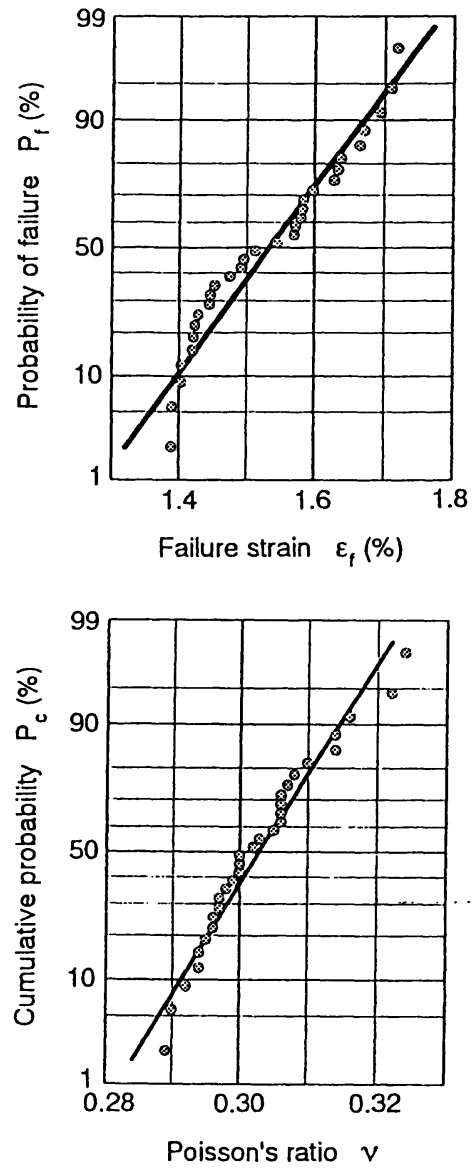

Fig. 3 Distributions of the mechanical properties of a T800H/PMR-15 laminate plotted on normal probability paper. 
Table 1 Central tendencies, scatter parameters, and B allowables of mechanical properties and specimen thickness in a Celion 6K/PMR-15 laminate.

\begin{tabular}{|c|c|c|c|c|c|c|}
\hline \multicolumn{2}{|c|}{$\begin{array}{l}\text { Parameter estimates } \\
\text { (Sample size } n=31 \text { ) }\end{array}$} & $\begin{array}{c}\text { Tensile } \\
\text { strength } \\
\mathrm{S}_{\mathrm{u}} \\
(\mathrm{MPa})\end{array}$ & $\begin{array}{c}\text { Failure } \\
\text { strain } \\
\varepsilon_{\mathrm{f}} \\
\text { ( } \mu \text { strain) }\end{array}$ & $\begin{array}{c}\text { Elastic } \\
\text { modulus } \\
E \\
(\mathrm{GPa})\end{array}$ & $\begin{array}{c}\text { Poisson's } \\
\text { ratio } \\
v\end{array}$ & $\begin{array}{c}\text { Thickness } \\
t \\
(\mathrm{~mm})\end{array}$ \\
\hline \multicolumn{2}{|r|}{ Median in data } & 616.7 & 13150 & 47.62 & 0.308 & 4.985 \\
\hline \multirow{4}{*}{ Normal } & Mean & 613.1 & 13240 & 47.05 & 0.307 & 4.989 \\
\hline & Standard deviation & 33.19 & 513.3 & 1.774 & 0.0129 & 0.0951 \\
\hline & Coefficient of variation (\%) & 5.41 & 3.88 & 3.77 & 4.22 & 1.91 \\
\hline & B allowable & 554.5 & 12330 & 43.91 & & \\
\hline \multirow{4}{*}{ Log-normal } & Log-mean & 2.7869 & 4.1214 & 1.6723 & -0.514 & 0.6979 \\
\hline & Median & 612.3 & 13230 & 47.02 & 0.306 & 4.988 \\
\hline & Log-standard-deviation & 0.02335 & 0.01651 & 0.01663 & 0.0185 & 0.00823 \\
\hline & B allowable & 556.8 & 12370 & 43.94 & & \\
\hline \multirow{5}{*}{ Extreme-value } & Location parameter & 627.3 & 13450 & 47.86 & 0.313 & 5.030 \\
\hline & Median & 617.9 & 13310 & 47.32 & 0.309 & 5.003 \\
\hline & Scale parameter & 25.58 & 377.2 & 1.460 & 0.0107 & 0.07393 \\
\hline & Equivalent CV (\%) & 4.14 & 2.83 & 3.09 & 3.46 & 1.48 \\
\hline & B allowable & 547.7 & 12270 & 43.32 & & \\
\hline \multirow{4}{*}{ 2P-Weibull } & Scale parameter & 626.6 & 13440 & 47.85 & 0.312 & 5.029 \\
\hline & Median & 617.1 & 13300 & 47.30 & 0.308 & 5.002 \\
\hline & Shape parameter & 23.98 & 35.35 & 31.73 & 28.3 & 67.55 \\
\hline & B allowable & 550.4 & 12300 & 43.38 & & \\
\hline
\end{tabular}

Table 2 Central tendencies, scatter parameters, and B allowables of mechanical properties in a T800H/PMR-15 laminate.

\begin{tabular}{|c|c|c|c|c|c|}
\hline \multicolumn{2}{|c|}{$\begin{array}{l}\text { Parameter estimates } \\
(\text { Sample size } n=30)\end{array}$} & $\begin{array}{c}\text { Tensile } \\
\text { strength } \\
\mathrm{S}_{u} \\
(\mathrm{MPa})\end{array}$ & $\begin{array}{c}\text { Failure } \\
\text { strain } \\
\varepsilon_{\mathbf{f}} \\
\text { ( } \mu \text { strain) }\end{array}$ & $\begin{array}{c}\text { Elastic } \\
\text { modulus } \\
E \\
(\mathrm{GPa})\end{array}$ & $\begin{array}{c}\text { Poisson's } \\
\text { ratio } \\
v\end{array}$ \\
\hline \multicolumn{2}{|r|}{ Median in data } & 790.6 & 15300 & 54.04 & 0.301 \\
\hline \multirow{4}{*}{ Normal } & Mean & 789.9 & 15340 & 54.36 & 0.303 \\
\hline & Standard deviation & 43.23 & 1057 & 1.647 & 0.00889 \\
\hline & Coefficient of variation (\%) & 5.47 & 6.89 & 3.03 & 2.94 \\
\hline & B allowable & 713.1 & 13460 & 51.43 & \\
\hline \multirow{4}{*}{ Log-normal } & Log-mean & 2.8969 & 4.1847 & 1.7351 & -0.519 \\
\hline & Median & 788.7 & 15300 & 54.34 & 0.303 \\
\hline & Log-standard-deviation & 0.02404 & 0.02980 & 0.01300 & 0.0126 \\
\hline & B allowable & 714.8 & 13550 & 51.52 & \\
\hline \multirow{5}{*}{ Extreme-value } & Location parameter & 809.6 & 15790 & 55.05 & 0.307 \\
\hline & Median & 796.6 & 15490 & 54.59 & 0.304 \\
\hline & Scale parameter & 35.55 & 818.7 & 1.246 & 0.00685 \\
\hline & Equivalent CV (\%) & 4.46 & 5.29 & 2.28 & 2.25 \\
\hline & B allowable & 698.4 & 13230 & 51.16 & \\
\hline \multirow{4}{*}{ 2P-Weibull } & Scale parameter & 808.9 & 15760 & 55.03 & 0.307 \\
\hline & Median & 795.5 & 15460 & 54.57 & 0.304 \\
\hline & Shape parameter & 21.89 & 18.70 & 43.80 & 44.3 \\
\hline & B allowable & 701.3 & 13330 & 51.24 & \\
\hline
\end{tabular}

とばらつきについてはほぼ同等とみなせる.

正規分布における B 許容値の片側許容限 係数 ${ }^{16)}$ は, $k_{\mathrm{B}}=1.777(n=30), 1.767(n=31)$ である. また，極 值分布における $\mathrm{B}$ 許容値を計算するための $V$ 值 ${ }^{17)}$ は, $V_{0.1}(0.95)=3.127(n=30), 3.111(n=31)$ である.
これらを用いて Table 1，2 に示すB許容値を導いた。

これらのB許容値を見ると, 極値分布を仮定する場合が 最も小さい值となり，2 母数ワイブル分布, 正規分布, 対数正規分布の順で大きくなる．ただし，あまり大きな 差はない. 
Table 3 Calculation of the modified Kolmogorov-Smirnov goodness-of-fit test statistics for the data of a Celion $6 \mathrm{~K} / \mathrm{PMR}-15$ laminate.

\begin{tabular}{|c|c|c|c|c|c|}
\hline $\begin{array}{l}\text { Distribution model } \\
\text { (Sample size } n=31)\end{array}$ & $\begin{array}{c}\text { Tensile } \\
\text { strength } \\
\mathrm{S}_{\mathrm{u}}\end{array}$ & $\begin{array}{c}\text { Failure } \\
\text { strain } \\
\varepsilon_{\mathbf{f}}\end{array}$ & $\begin{array}{c}\text { Elastic } \\
\text { modulus } \\
\text { E }\end{array}$ & $\begin{array}{c}\text { Poisson's } \\
\text { ratio } \\
v\end{array}$ & $\begin{array}{c}\text { Thickness } \\
\mathbf{t}\end{array}$ \\
\hline Normal & 0.137 & 0.109 & $\underline{0.157}$ & 0.113 & 0.097 \\
\hline Log-normal & 0.136 & 0.102 & 0.162 & 0.117 & 0.093 \\
\hline Extreme-value & $\underline{0.166}$ & $\underline{0.174}$ & 0.103 & 0.094 & 0.152 \\
\hline 2P-Weibull & 0.164 & 0.166 & 0.106 & 0.086 & 0.148 \\
\hline
\end{tabular}

\section{3 各機械的性質の 4 種類の分布モデルに対する 適 合度評価}

ここでは 4 種類の分布形に対して,修正コルモコロフ・ スミルノフ適合度検定の統計量により相対的な適合度 を比較するとともに，各分布形に対する適合度を検定す る. 式(16)により計算された $D_{n}$ の值を Table 3,4 に 示す.これらの㳖において $D_{n}$ 値の小さいほうがあては まりが良いと判定する. Table 1 と 2 に示したようにい すれれ特性も統計的分布としてのばらつきは余り大きく ないので，もとの变数による分布と対数変換した分布， すなわち正規分布に対する対数正規分布，極值分布に対 する 2 母数ワイブル分布とではそれぞれあまり大きな差 がないことがわかる. Table 3，4を見ると，ワイブル 系分布が正規系分布よりあてはまりが良いのは，Celion 6K/PMR-15 の弾性係数とポアソン比のみである. T800H/PMR-15 の場合は, 弾珄係数とポアソン比につ いても正規系分布のほうがあてはまりが良いことがわか る. 以上の点と分布形も標本ごとにばらつくことの両方 を考虑すると, 全体的に正規系分布をあてはめても妥当 であるように思われる．正規分布と対数正規分布の選択 については，差が小さいのでどちらを選択してもよいと 思われるが，正規分布を選択するほらが取り扱いは容易 である.

なお，有意水準 $5 \%$ に対応する修正コルモゴロフ・ス ミルノフ適合度検定の限界値 ${ }^{19)}$ は, 試験個数 $n=30$ 拧 よび 31 の場合，正規系分布に対してそれぞれ 0.159 お よび 0.156, ワイブル系分布に対してそれぞれ 0.163 お よび 0.161 である. この值以上になれば葉却される. Table 3，4 を見ると棄却されるるのがいくつか存在し， 数値に下線を引いて示した。

前記したように, Fig. 2，3 には各機械的性質と試験 片厚さの分布を正規確率紙にプロットして示した. この ように，確率紙にデータをプロットして適合度を直感的 に判定することも一般的である.ここでは紙面の都合 で，4種類の確率紙にプロットしたグラフを揭载できな
Table 4 Calculation of the modified KolmogorovSmirnov goodness-of-fit test statistic for the data of a T800H/PMR-15 laminate.

\begin{tabular}{c|cccc}
\hline $\begin{array}{c}\text { Distribution model } \\
\text { (Sample size } n=30)\end{array}$ & $\begin{array}{c}\text { Tensile } \\
\text { strength } \\
\mathrm{S}_{u}\end{array}$ & $\begin{array}{c}\text { Failure } \\
\text { strain } \\
\varepsilon_{\mathrm{f}}\end{array}$ & $\begin{array}{c}\text { Elastic } \\
\text { modulus } \\
\mathrm{E}\end{array}$ & $\begin{array}{c}\text { Poisson's } \\
\text { ratio } \\
v\end{array}$ \\
\hline Normal & 0.077 & 0.141 & 0.154 & 0.126 \\
Log-normal & 0.084 & 0.138 & 0.148 & 0.123 \\
Extreme-value & 0.136 & $\underline{0.172}$ & $\underline{0.212}$ & $\underline{0.185}$ \\
2P-Weibull & 0.126 & $\underline{0.168}$ & $\underline{0.205}$ & $\underline{0.181}$ \\
\hline
\end{tabular}

いが，上記のようにそれぞれのデータは正規と対数正規 確率紙，あるいは極值とワイブル確率紙それぞれの上で の適合度はほとんど違いがなかった。 なお，Table 3，4 においてワイブル系の分布にあてはまりの良い場合，す なわち, Celion 6K/PMR-15 の弾性係数とポアンン比の 場合のデータ分布は，正規確率紙上で右斜め下向きに凸 の形状となることがわかる.

\section{4 機械的性質間における相関関係の検討}

機械的珄質間の関連を調べるために，相関関係を計算 する. 得られた相関係数行列を Table 5, 6 に示す. 相 関係数の比較的大きいものは, Celion 6K/PMR-15 の場 合，引張強度と破断昰，引張強度と弾性係数の関係であ る. 一方, T800H/PMR-15 の場合は引張強度と破断稆 の関係のみである. 引張強度と弾性係数の関係について は，共通な相関が得られていないまた，王縮強度の場 合には比較的影響が大きいと考えられた板厚との関係 ${ }^{200}$

Table 5 Correlation coefficient.matrix for the data of a Celion 6K/PMR-15 laminate.

\begin{tabular}{c|ccccc}
\hline & $\begin{array}{c}\text { Tensile } \\
\text { strength } \\
\mathrm{S}_{\mathrm{u}}\end{array}$ & $\begin{array}{c}\text { Failure } \\
\text { strain } \\
\varepsilon_{\mathrm{f}}\end{array}$ & $\begin{array}{c}\text { Elastic } \\
\text { modulus } \\
\mathrm{E}\end{array}$ & $\begin{array}{c}\text { Poisson's } \\
\text { ratio } \\
v\end{array}$ & $\begin{array}{c}\text { Thickness } \\
\mathrm{t}\end{array}$ \\
\hline $\mathrm{S}_{\mathrm{u}}$ & 1.000 & & & & \\
$\varepsilon_{\mathrm{f}}$ & 0.704 & 1.000 & & & \\
$\mathrm{E}$ & 0.736 & 0.047 & 1.000 & & \\
$v$ & 0.459 & 0.251 & 0.429 & 1.000 & \\
$\mathrm{t}$ & 0.138 & 0.143 & 0.063 & -0.135 & 1.000 \\
\hline
\end{tabular}


Table 6 Correlation coefficient matrix for the data of a T800H/PMR-15 laminate.

\begin{tabular}{c|cccc}
\hline & $\begin{array}{c}\text { Tensile } \\
\text { strength } \\
\mathrm{S}_{u}\end{array}$ & $\begin{array}{c}\text { Failure } \\
\text { strain } \\
\varepsilon_{\mathrm{f}}\end{array}$ & $\begin{array}{c}\text { Elastic } \\
\text { modulus } \\
\mathrm{E}\end{array}$ & $\begin{array}{c}\text { Poisson's } \\
\text { ratio } \\
v\end{array}$ \\
\hline $\mathrm{S}_{\mathrm{u}}$ & 1.000 & & & \\
$\varepsilon_{\mathrm{f}}$ & 0.608 & 1.000 & & \\
$\mathrm{E}$ & 0.233 & -0.471 & 1.000 & \\
$v$ & 0.145 & 0.007 & 0.207 & 1.000 \\
\hline
\end{tabular}

については, Celion 6K/PMR-15 の引張強度と板厚との 関係をみると，相関が小さいことがわかる.なおここで は，相関係数の比較的大きい場合を含む引張強度と破断 怸および弾性係数との闒係を Fig. 4, 5 に示す. 図上に は, 破断歪または弾性係数を独立变数，引張強度を従属 変数とした回帰直線を描いて示す。これらの図により両 者の㑑関の様子を理解できる.

\section{5 重回帰分析}

上記したように, 引張強度と破断歪，引張強度と弾性 係数の相関関係が比較的大きいことがわかった. そこ
で，ここでは引張強度の予测を目的として，破断歪と弾 珄係数により引張強度が導かれるとして重回帰分析を試 みる. るちろん引張強度と破断歪は同時に起きる事象で あるから，どちらが目的変数でどちらが説明変数である とは言えないが，このように仮定して議論する.

式(19)において，引張強度を $z$ ，破断歪を $x$, 弾性係 数を $y$ と扰く．上記した相関係数行列と式(20)による標 準偏差を計算し， $a ， b_{1}, b_{2}$ ，および重相関係数を導き， Table 7 に示す. また, Fig. 6(a)と(b)にはこれらの回帰 式を使い，予测値と実験値との比較を示す. Celion 6K/ PMR-15 の場合の重相関係数が約 1 であるから, 破断歪 と弾性係数の 2 変数による関数として表される引張強度 は，予測值と実験値がく合うことがわかる。これは Fig. 6(a)に示したと拈りである. また Fig. 4 と比較す ると，予测直線からのデータのちらばりが非常に小さい ことがかかる. 一方, T800H/PMR-15 の場合は, 0.85 であるから Celion 6K/PMR-15 の場合より劣るが，一 つの変数の関数とした Table 6 の場合に比べて大幅に
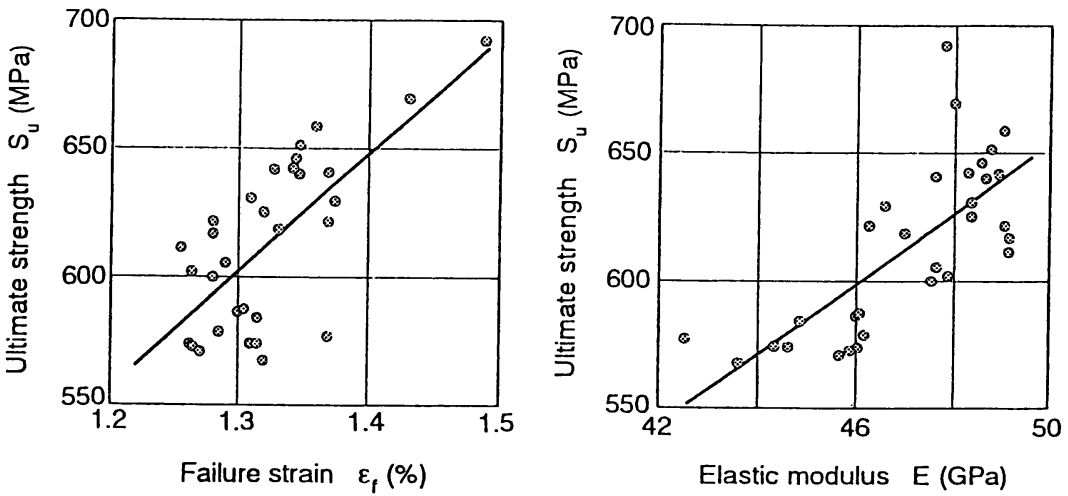

Fig. 4 Correlation between the mechanical properties of a Celion 6K/PMR-15 laminate.
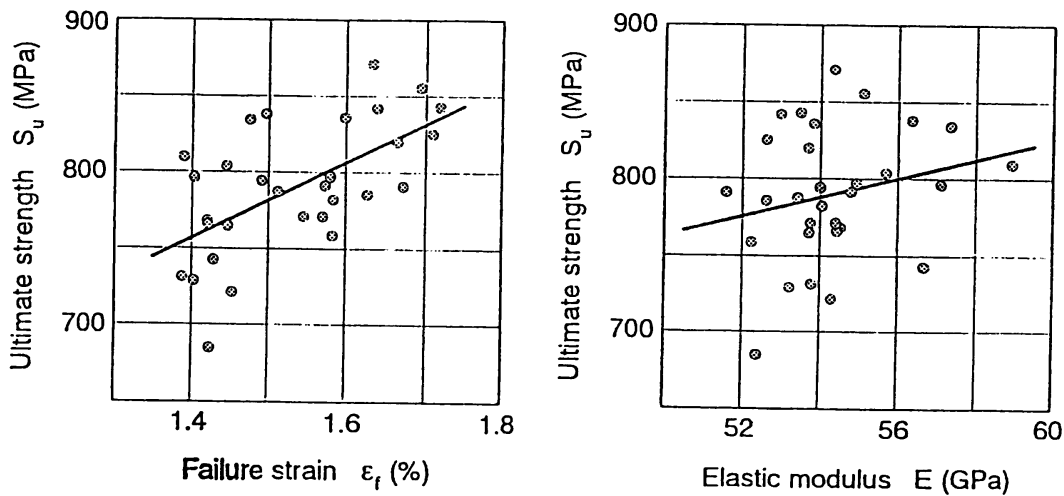

Fig. 5 Correlation between the mechanical properties of a T800H/PMR-15 laminate. 


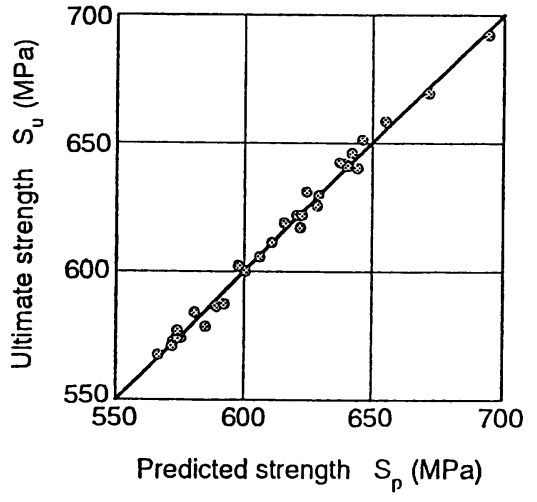

(a) Celion 6K/PMR-15

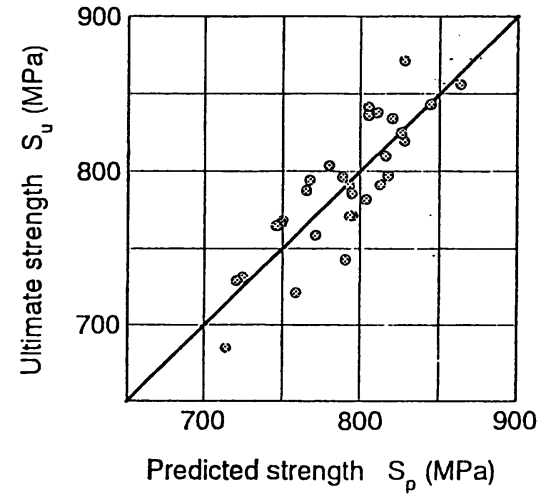

(b) T80OH/PMR-15

Fig. 6 Strength prediction by multiple regression analysis for both materials.

Table 7 Results of multiple regression analysis.

\begin{tabular}{c|ccc|c}
\hline \multirow{2}{*}{ Material } & \multicolumn{3}{|c|}{ Regression coefficients } & MCC* \\
\cline { 2 - 4 } & $\mathrm{a}$ & $\mathrm{b}_{1}$ & $\mathrm{~b}_{2}$ & $\mathrm{R}_{\mathrm{m}}$ \\
\hline Celion 6K/PMR-15 & -581.1 & 0.04337 & 13.18 & 0.9953 \\
T800H/PMR-15 & -743.5 & 0.03777 & 17.55 & 0.8469 \\
\hline
\end{tabular}

Multiple correlation coefficient.

改善されている.これは Fig. 5 と Fig. 6(b) を比較す ることによっても理解できる.

\section{5. 結言}

2 種類のカーボン/ボリイミド染等方積層複合材料平 滑試験片について, 室温で統計的引張試験を行い, 機械 的性質の統計的な特性を調べた. 得られた結論の主なる のを以下に列挙する.

（1）引張強度, 破断歪, および弾性係数の代表値につ いて, T800H/PMR-15 は Celion 6K/PMR-15 に比べ て非常に優れた結果を示した。これらのばらつきを変動 係数により比べると，破断雪の場合は T800H/PMR-15 のほうが Celion 6K/PMR-15 の場合より大きいが, こ れ以外は同等とみなせた。 ポフンン比については, 代素 値、ばらつきともに同等とみなせた。

（2）引張強度, 弾性係数, および破断歪のB許容值を 分布モデル別に導いたところ，極值分布を仮定する場合 が最も小さく，2母数ワイブル分布，正規分布, 対数正 規分布の順で大きくなる，たたし，互いにあまり大きな 差はなかった。

（3）各機械的性質の 4 種類の分布モデルへの適合度を 検討した結果, 正規系の正規分布と対数正規分布との 差, およびワイブル系の極值分布と 2 母数ワイブル分布
との差はそれぞれあまり大きくなかった。

(4) 正規系分布とワイブル系分布への適合度の比較で は，ワイブル系分布が正規系分布よりあてはまりが良い のは, Celion 6K/PMR-15 の弾性俰数とポアンン比のみ であり，他の場合は正規系分布のほうがよりよくあては まった．全体的に正規分布をあてはめることは妥当であ ると考えられた.

（5）相関係数が比較的大きいのは, Celion 6K/PMR15 の場合, 引張強度と破断䄳, 引張強度と弾性係数の関 係であり, T800H/PMR-15 の場合は, 引張強度と破断 歪の関係のみであった.

（6）引張強度は破断歪と弾性係数に依存すると仮定し て，重回帰分析を実施した結果，Celion 6K/PMR-15 の 場合の重相関係数は約 1 であり，T800H/PMR-15 の場 合は， 0.85 であった. すなわち， 2 種の材料について 重回帰分析により導いた引張強度の予测式は実験値と比 校的よく一致した.

本研究を遂行するにあたり, 富士重工の菊川広繁氏か ら各種のご助言を頂いた. ここに厚く感謝申し上げる.

\section{参考文 献}

1) H.B. Dexter \& J.G. Davis, Jr., eds. : Graphite/ Polyimide Composites, NASA CP 2079 (1979).

2) High Temperature Polymer Matrix Composites, NASA CP-2385 (1985).

3) T.T. Serafini \& M.P. Hanson : Composites for Extreme Environments, ASTM STP 768, N.R. Adsit, ed. (1982), pp. 5-19.

4) S.C. Kunz : Composites for Extreme Environments, ASTM STP 768, N.R. Adsit, ed. (1982), 
pp. 33-53.

5) D.P. Garber, D.H. Morris \& R.A. Everett, Jr. : Composites for Extreme Environments, ASTM STP 768, N.R. Adsit, ed. (1982), pp. 73-91.

6) J.B. Nelson : Long-Term Behavior of Composites, ASTM STP 813, T.K. O'Brien, ed. (1983), pp. 206-221.

7) S.F. McCleskey, J.B. Cushman \& D.E. Skoumal : AIAA Paper 82-0707, Proc. SDM Conf. (1982), pp. 212-222.

8) D.W. Wilson, R.B. Pipes, D. Riegner \& J. Webster: Test Methods and Design Allowables for Fibrous Composites, ASTM STP 734, C.C. Chamis, ed. (1981), pp. 195-207.

9）角田義秋，濱口泰正，野口義男，三本木茂夫，下 河利行, 松下 正, 山本昌孝, 渥美基広 : 第 31 回構造強度に関する講演会講演集, 日本航空宇宙 学会・日本機械学会 (1989)，pp. 56-59.

10）濱口泰正，下河利行，三本木茂夫，角田義秋，野 口義男，松下 正，山本昌孝，渥美基広：第 31 回構造強度に関する講演会請演集, 日本航空宇宙 学会・日本機械学会 (1989), pp. 60-63.

11）下河利行，濱口泰正，三本木茂夫，角田義秋，野 口義男，松下 正，山本昌孝，渥美基広 : 第 31 回構造強度に関する講演会講演集，日本航空宇宙
学会・日本機械学会 (1989), pp. 64-67.

12) 三本木茂夫 : 第 31 回構造強度に関する講演会講 演集，日本航空宇宙学会・日本機械学会（1989）, pp. 68-71.

13）富岡史城，夏村 匡：第 18 回複合材料シンボジ ウム講演要旨集, 日本複合材料学会 (1993), pp. 87-90.

14）下河利行：実製品の信頼性創造技術シンポジウム 講演論文集 No. 910-49，日本機械学会 (1991)， pp. 1-6.

15) MIL-HDBK-5F, Metallic Materials and Elements for Aerospace Vehicle Structures, Department of Defense, U.S.A. (1990).

16）山内二郎他編：統計数値表，JSA-1972，日本規格 協会（1972）

17) 下河利行：材料，41，468（1992)，1446-1451.

18) N.R. Mann, R.E. Schafer \& N.D. Singpurwalla: Methods for Statistical Analysis of Reliability and Life Data, John Wiley \& Sons, New York (1974), p. 349.

19) 下河利行：材料, 39, 436 (1990)， 45-49.

20）濱口泰正，下河利行，角田義秋：第 34 回楧造強 度に関する講演会講演集, 日本航空字宙学会・日 本機械学会 (1992), pp. 286-289. 